\title{
Merefleksi Kembali Buku Berkonten Misteri
}

\author{
Deski Firdiansyah
}

Artikel ini merupakan pengembangan dari tulisan dan ulasan yang saya pernah tuliskan sebelumnya. Saya termasuk orang yang gemar membaca buku. Bagi saya membaca buku tak lain merupakan sebuah aktivitas literasi yang berkesan dan mengasyikkan. Ketika membaca sebuah buku, saya akan berusaha untuk menamatkannya sesegera mungkin. Pada kesempatan ini, saya ingin sedikit berbagi cerita tentang sebuah buku yang kebetulan saya beli beberapa waktu lalu. Buku tersebut berjudul "Manusia-manusia Paling Misterius di Dunia" (2012).

Bagi orang yang suka terhadap misteri seperti saya, buku yang ditulis oleh Eka Nada Shofa Alkhajar ini memberikan gambaran yang cukup terang dan boleh dikatakan kesimpulan (conclusion) terhadap beberapa "misteri besar dunia" yang sampai sekarang belum terungkap. Di samping menyajikan kesimpulan terhadap tokohtokoh yang diangkat, buku ini juga menyajikan berbagai referensi mengenai informasi sejarah maupun informasi terkait lainnya dari setiap tokoh. Hal itulah yang membuat buku ini semakin menarik dan selalu asyik untuk diikuti dari awal sampai akhir.

Dari segi bahasa, buku ini boleh saya bilang mendapat nilai 9,4 dari 10 angka sempurna. Kenapa saya katakan demikian, karena saya dapat membaca habis buku ini dalam waktu akumulatif 24 jam. Hanya dua hari saya baca and finally done. Yang paling penting, buku ini tidak pernah membuat saya menguap bosan. Boleh saya katakan bahasanya benar-benar mengalir mengikuti aliran misteri menarik yang diangkat.

Apa yang membuat buku ini mendekati sempurna menurut saya adalah karena buku ini tidak hanya mengangkat aspek kisah para tokoh yang dikatakan termasuk manusia-manusia paling misterius. Lebih dari itu, buku ini menuliskan ulasan kisah para tokoh tersebut dengan merujuk kepada data dan fakta yang ada sebagaimana dianalisis oleh penulisnya. Semua ulasan disajikan secara faktual dan dilengkapi berbagai referensi serta sumber-sumber yang dapat dipertanggungjawabkan (misalnya Blundell, 1980; Rosenberg, 2001; Mercatante \& Dow, 2009). Itu semua bisa dikatakan sebagai salah satu formula ampuh untuk menulis buku berkonten misteri sebagaimana dipraktikkan oleh buku yang telah tuntas saya baca ini. 
Kalau saya boleh berpendapat, kemungkinan besar penulis buku ini pasti sering menulis ataupun menyusun tulisan hingga buku ilmiah tebal yang menyita waktu. Jarang sekali saya temui buku konvensional yang memuat literatur-literatur yang lengkap dan menarik. Setelah saya telusuri memang benar penulisnya telah banyak menulis tulisan ilmiah. Pantas saja. Dari proses pencarian tersebut saya juga mendapatkan beberapa informasi dan literatur penting.

Buku ini sesungguhnya juga termasuk ke dalam buku serius karena penulisnya berupaya mengulas mengenai industri budaya yang memang secara disiplin keilmuan agak berjauhan dengan apa yang saya tekuni. Kemudian, ada pula konsep menarik mengenai komodifikasi yang mana berkaitan erat dengan modal, komoditas dan pasar (Alkhajar, 2014b: 125).

Oleh karena saya tertarik untuk mengetahui perihal industri budaya lebih jauh maka saya pun melakukan penelusuran literatur tentang industri budaya hingga akhirnya mendapatkan sebuah buku bacaan menarik karya Adorno (1991). Minat saya untuk membaca literatur-literatur lain berkenaan dengan kajian budaya pun menjadi semakin besar. Apalagi aspek serta ruang dimensinya demikian luas sehingga sangat menarik untuk didalami di mana saya pun akhirnya membaca buku karya Barker (2000). Hal tersebut tak lain juga karena distimulasi oleh buku berkonten misteri yang saya ulas ini.

Menurut pendapat saya, tidak sulit untuk memahami gagasan utama dari industri budaya berdasarkan apa yang dituliskan oleh penulisnya di buku ini. Hal ini dikarenakan penulisnya telah memberikan sebuah pengantar apik mengenai konsep tersebut. Di sisi lain, penulis buku ini nyatanya memang dapat dikatakan kerap menuliskan gagasan yang pokok utamanya sama, yakni masih berkaitan erat dengan industri budaya (misalnya Alkhajar, 2010, 2011, 2014a).

Secara keseluruhan buku ini menurut saya sangat baik. Buku ini cocok untuk dibaca dan dinikmati sebagai hiburan, pengisi waktu, penambah pengetahuan, serta dapat pula disimpan sebagai referensi bacaan dalam memfilter kepercayaan terhadap suatu misteri. Oleh karena itu, buku ini termasuk ke dalam daftar buku yang saya rekomendasikan untuk dibaca. This is a recommended book.

\section{Referensi}

Adorno, T. W. (1991). The Culture Industry. London: Routledge. 
Alkhajar, E. N. S. (2010). Sinetron dalam Jeratan Industri Budaya. Pelita, 29 April.

Alkhajar, E. N. S. (2011). Menguak Mitos dan Legenda dalam Balutan Industri Budaya. Komunikasi Massa, 4(2).

Alkhajar, E. N. S. (2012). Manusia-Manusia Paling Misterius di Dunia. Surakarta: BukuKatta.

Alkhajar, E. N. S. (2014a). Media, Masyarakat dan Realitas Sosial. Surakarta: Sebelas Maret University Press.

Alkhajar, E. N. S. (2014b). Kekerasan Media: Kapitalisme, Industri Budaya, dan Masyarakat Tontonan. Ultima Humaniora, 2(1), 124-131.

Barker, C. (2000). Cultural Studies: Theory and Practice. London: Sage Publications.

Blundell, N. (1980). The World's Greatest Mysteries. London: Octopus Books.

Mercatante, A. S., \& Dow, J. R. (2009). The Facts on File Encyclopedia of World Mythology and Legend. Third edition. New York: Facts on File, Inc.

Rosenberg, D. (2001). World Mythology: An Anthology of the Great Myths and Epics. London: McGraw-Hill. 